\title{
Effects of high pressure on functionality of whey protein concentrate and whey protein isolate
}

\author{
Greta KREŠIĆa*, Vesna LELAS ${ }^{b}$, Zoran HERCEG $^{b}$, Anet REŽEK ${ }^{b}$ \\ a Faculty of Tourism and Hospitality Management, University of Rijeka, Primorska 42, \\ PO Box 97, 51410 Opatija, Croatia \\ b Faculty of Food Technology and Biotechnology, University of Zagreb, Pierrottijeva 6, \\ 10000 Zagreb, Croatia
}

Received 22 July 2005 - Accepted 29 May 2006

\begin{abstract}
The objective of this study was to evaluate the influence of high-pressure treatments on the solubility, surface hydrophobicity, foaming and emulsifying ability of whey protein concentrate (WPC) and whey protein isolate (WPI). Dispersions of WPC and WPI powders (10\% (w/w)) were processed at $300 \mathrm{MPa}$ and $600 \mathrm{MPa}$, for 5 and $10 \mathrm{~min}$ at $40 \pm 2{ }^{\circ} \mathrm{C}$. Changes in protein solubility were determined as solubility at $\mathrm{pH} 7.0$ and at $\mathrm{pH}$ 4.6. Assessment of foaming properties was based on the foam expansion during prolonged whipping, and foam stability. Emulsifying properties were characterised by emulsion stability and emulsifying activity indices. The results show significant $(P<0.05)$ modification of solubility and surface hydrophobicity with increasing intensity and duration of applied pressure, indicating partial denaturation and aggregation of proteins. It was found that high-pressure treatments significantly $(P<0.05)$ improved the foaming behaviour of WPI, while the foaming ability of WPC was diminished. However, foams formed with high-pressuretreated WPC and WPI exhibited significantly prolonged stability $(P<0.05)$ compared with control samples. There was a significant trend of decreasing emulsifying efficiency and emulsifying stability related to the intensity of applied pressure and treatment time for both WPC and WPI.
\end{abstract}

emulsifying properties / foaming properties / high pressure / whey protein concentrate / whey protein isolate / solubility / surface hydrophobicity

摘要 - 高压处理对乳清浓缩蛋白和乳清分离蛋白的影响。本文研究了高压处理对乳清浓缩 蛋白 (WPC) 和乳清分离蛋白 (WPI) 的溶解性、表面疏水性、发泡性和乳化性的影响。在 $40{ }^{\circ} \mathrm{C}$ 下, 乳清浓缩蛋白 $(10 \%, \mathrm{w} / \mathrm{w})$ 和乳清分离蛋白 $(10 \%, \mathrm{w} / \mathrm{w})$ 的分散液分别在 $300 \mathrm{MPa}$ 和 $600 \mathrm{Mpa}$ 下高压处理 $5 \mathrm{~min}$ 和 $10 \mathrm{~min}$ 。在 $\mathrm{pH} 7.0$ 和 $\mathrm{pH} 4.6$ 测定了两种蛋白质溶解性的变 化。以长时间搅打后形成的泡沫膨胀度和泡沫稳定性来评价蛋白质的发泡性能; 根据测定 乳液稳定性指数和乳化活性指数评价两种蛋白质的乳化特性。试验结果表明, 经过高压长 时间的处理后, 由于蛋白质发生了部分变性和凝聚作用, 使得蛋白质的溶解性和表面疏水 性发生了显著的改变 $(P<0.05)$ 。高压处理能够显著地改善 WPI 的发泡性 $(P<0.05)$, 而 WPC 的泡沫形成能力则降低。然而与对照样品相比, 经过高压处理后的 WPC 和 WPI 形成的泡 沫稳定性有显著提高 $(P<0.05)$ 。随着处理压力和作用时间的增加, 两种蛋白质的乳化性和 乳化稳定性均呈下降的趋势。

乳化性 / 发泡性 / 高压 / 乳清浓缩蛋白 / 乳清分离蛋白 / 溶解性 / 表面疏水性

\footnotetext{
* Corresponding author (通讯作者): Greta.Kresic@fthm.hr
} 
Résumé - Effets des hautes pressions sur la fonctionnalité d'un concentré et d'un isolat de protéines de lactosérum. L'objectif de cette étude était d'évaluer l'influence des traitements haute pression sur la solubilité, l'hydrophobicité de surface, le pouvoir moussant et émulsifiant d'un concentré (WPC) et d'un isolat (WPI) de protéines de lactosérum. Les dispersions de poudres WPC ET WPI $(10 \% \mathrm{w} / \mathrm{w})$ étaient traitées à $300 \mathrm{MPa}$ et $600 \mathrm{MPa}$ pendant 5 et $10 \mathrm{~min}$, à $40 \pm 2{ }^{\circ} \mathrm{C}$. Les changements de solubilité des protéines étaient déterminés à $\mathrm{pH} 7.0$ et à $\mathrm{pH} 4.6$. L'évaluation des propriétés moussantes était basée sur l'expansion de la mousse au cours d'un fouettage prolongé et sur la stabilité de mousse. Les propriétés émulsifiantes étaient caractérisées par la stabilité de l'émulsion et les indices d'activité émulsifiante. Les résultats ont montré une modification significative $(P<0,05)$ de la solubilité et de l'hydrophobicité de surface avec l'application d'une pression de durée et d'intensité croissantes, indiquant une dénaturation partielle et l'agrégation des protéines. Il a été démontré que les traitements haute pression amélioraient de façon significative $(P<0,05)$ le comportement moussant de l'isolat de protéines de lactosérum, tandis que la capacité moussante du concentré de protéines était diminuée. Cependant, les mousses formées avec le WPC et le WPI traités par haute pression montraient une stabilité significativement prolongée $(P<0,05)$ par rapport au témoin. Une tendance significative à la diminution de l'efficacité émulsifiante et de la stabilité de l'émulsion, liée à l'intensité de la pression appliquée et de la durée de traitement, était observée aussi bien pour le WPC que le WPI.

propriété émulsifiante / propriété moussante / haute pression / concentré de protéines de lactosérum / isolat de protéines de lactosérum / solubilité / hydrophobicité de surface

\section{INTRODUCTION}

Whey protein isolate (WPI) and whey protein concentrate (WPC) are used as food ingredients due to their commercially important functional properties such as solubility, viscosity, water-holding capacity, gelation, adhesion, emulsification and foaming [45]. As foodstuffs they are applied not only because of their functional properties, but also because of their high nutritive value, reasonable cost and GRAS status [14].

Generally, the functional properties of food proteins may be classified into three main groups: (a) hydration properties, dependent upon protein-water interactions which have an important bearing on wetability, swelling, adhesion, dispersibility, solubility, viscosity, water absorption and water holding; (b) interfacial properties including surface tension, emulsification and foaming characteristics; and (c) aggregation and gelation properties, which are related to protein-protein interactions $[3,7$, 19]. Improvements in functional properties may be achieved by modifying the protein structure by chemical, enzymatic or physical treatments $[11,15,16,18,24,28,37$, 43]. Functional properties of whey proteins such as emulsification, foaming and gela- tion are affected by their structure and mainly reflect the functionality of $\beta$-lactoglobulin as the most abundant protein, which has the ability to adsorb at the wateroil and air-water interfaces [39]. Some studies on the influence of pressure on pure $\beta$-lactoglobulin have indicated that high pressure had a notable effect on its conformational and aggregation properties, affecting its functionality [13]. However, functionality of WPC and WPI modified by high pressure still does not meet the expectations which could realise the full potential of these food ingredients in industrial application $[23,31]$.

The increased interest in novel technologies using mild treatments and without addition of chemicals are nowadays very much in demand. Although the effect of high pressure on food systems was first reported over 100 years ago, it is only in recent years that this technology has been seriously considered as a viable method of food processing and preservation [30]. One of the important aspects of pressure treatment is that food can be processed with minimal effect on the natural colour, flavour, taste and texture with little or no loss of vitamins [44]. High pressure has also been used as an effective technique of altering the surface 
functional properties of water-soluble proteins $[25,35]$. Pressure acts as a physicochemical parameter that alters the balance of intramolecular and solvent-protein interactions. Low protein concentrations and pressures up to $200 \mathrm{MPa}$ usually result in reversible pressure-induced denaturation. Higher pressures (above $300 \mathrm{MPa}$ ) have irreversible and extensive effects on proteins, including denaturation due to unfolding of monomers, aggregation and formation of gel structures [5]. The extent of high-pressure-induced denaturation of whey proteins increases with treatment time [21, 22], treatment temperature [17] and $\mathrm{pH}$ [2]. The application of pressure has a disruptive effect on intramolecular hydrophobic and electrostatic interactions. As hydrogenbonding interactions are relatively insensitive to pressure, high pressure disrupts the quaternary and tertiary structure of globular proteins with relatively little influence on their secondary structure [48].

The relevance of the present study lies in the use of a commercial WPC and WPI rather than conventionally produced proteins that are obtained by $\mathrm{pH}$ modification and ion exchange chromatography, and in the use of hydrostatic high-pressure treatment (up to $600 \mathrm{MPa}$ ) in model systems similar to commercial food systems. Selected WPC and WPI are good candidates for testing the practical utility of the application of high pressure to modify the functional properties of a complex protein system since they are in the form that the ingredients are utilised in a number of food applications. Moreover, several authors $[26,47]$ have observed gelation of whey proteins after pressure processing at concentrations up to $12 \%(\mathrm{w} / \mathrm{w})$. In this respect, the objective of this work was to elucidate the effect of high-pressure treatment on dispersions of whey proteins at a concentration which is close to but insufficient for gelation, on the functional properties. Functionality was limited to solubility, foaming and emulsifying performance testing. We suppose that this research could encourage attempts to use these ingredients in a wide range of formulated food products to fully replace traditional additives such as milk powder or skim milk.

\section{MATERIALS AND METHODS}

\subsection{Whey proteins}

The WPC sample (Milacteal 60), obtained by ultrafiltration of casein serum, was purchased from Molkerei Strothmann (Guestersloh, Germany). The WPI sample (BiPRO) was kindly provided by Davisco Foods International (Le Sueur, MN, USA). Single batches were used without further purification. According to the manufacturers, the typical composition of this WPC on a dry basis was $61.3 \%$ protein, $4.5 \%$ ash, $26.8 \%$ lactose and $7.4 \%$ lipids, while the WPI contained (on a dry basis) $97.8 \%$ protein, $1.7 \%$ ash and $0.5 \%$ lipids.

WPI and WPC powders were each dissolved in distilled water by gentle magnetic stirring for $30 \mathrm{~min}$ to provide a $10 \%$ powder $(\mathrm{w} / \mathrm{w})$ dispersion and allowed to stand overnight at $4{ }^{\circ} \mathrm{C}$ before pressurisation. These extra storage periods contribute to the removal of foam bubbles and the completion of the hydration step. The $\mathrm{pH}$ values (at $20^{\circ} \mathrm{C}$ ) of the prepared dispersions were 6.47 for WPC and 6.92 for WPI, respectively.

\subsection{High-pressure treatment}

The pressure treatment was carried out in a LAB 50 single processor machine (SIG Simonazzi, Parma, Italy), at pressure levels of 300 and $600 \mathrm{MPa}$ with holding times of 5 and $10 \mathrm{~min}$. The samples $(170 \mathrm{~mL})$ were placed in PET bottles $(45 \times 135 \mathrm{~mm})$ with a screw cap (internal diameter of $30 \mathrm{~mm}$ ) and put into the high-pressure vessel of the processor through its upper opening. Care was taken not to leave any headspace between the closed screw cap and the liquid solution. Several samples in bottles were retained as controls. The vessel $(400-\mathrm{mL}$ capacity, $50 \mathrm{~mm}$ in diameter), made of the highest strength steel, was filled with a compression liquid (water-glycol mixture; $55 / 45, \mathrm{v} / \mathrm{v}$ ) in order to isostatically transfer the high pressure. The pressure was raised to $300 \mathrm{MPa}$ in $1 \mathrm{~min} 10 \mathrm{~s}$, maintained at $300 \mathrm{MPa}$ for 5 or $10 \mathrm{~min}$, then released in $45 \mathrm{~s}$. For pressurisation at $600 \mathrm{MPa}$, the pressure was raised in $1 \mathrm{~min} 55 \mathrm{~s}$, maintained for 5 or $10 \mathrm{~min}$, then released in $55 \mathrm{~s}$. 
The equipment was installed in an air-conditioned laboratory at $20^{\circ} \mathrm{C}$. Each sample was pressure-treated at a process temperature $\left(40 \pm 2{ }^{\circ} \mathrm{C}\right)$, taking into account the adiabatic heating which occurs during the compression phase. Compression was accompanied by an increase in temperature of $3.0-3.3{ }^{\circ} \mathrm{C}$ per $100 \mathrm{MPa}$. The temperature in the centre of the pressurisation chamber was measured using a thermocouple. Since pressurisation up to $600 \mathrm{MPa}$ and starting from room temperature leads to a temperature increase of almost $20^{\circ} \mathrm{C}$, for lower pressure levels, prior to compression, samples were placed in a thermostated chamber, and after the samples reached the desired temperature hydrostatic pressure was applied (i.e. to reach $40^{\circ} \mathrm{C}$ at $300 \mathrm{MPa}$ the samples were kept at $31^{\circ} \mathrm{C}$ ). The whole pressure generation system is fully automated; a proportional valve and pressure feedback allow tuneable and very reproducible pressure cycles. Immediately after pressure treatment pressure-treated and control samples were frozen in a blast freezer at $-50{ }^{\circ} \mathrm{C}$ and then freeze-dried at $10^{-2} \mathrm{~Pa}$ (for $48 \mathrm{~h}$ ) [41]. Protein powder was transferred into plastic bags, hermetically closed and stored over dried silica gel until analysed.

\subsection{Determination of protein solubility}

Protein solubility, expressed in g of soluble nitrogen per $100 \mathrm{~g}$ of total nitrogen, was determined according to the modified method described by Funtenberger and coworkers [12]. After pressure processing, freeze-dried protein powders were dissolved with deionised water to obtain a protein concentration of $1 \%(\mathrm{w} / \mathrm{w})$. The $\mathrm{pH}$ was adjusted to 4.6 or 7.0 with $0.025 \mathrm{~mol} \cdot \mathrm{L}^{-1} \mathrm{HCl}$ or $\mathrm{NaOH}$. Protein solutions were then centrifuged at $12000 \times g$ for 15 min (Beckman model J-21B). Nitrogen in the supernatant was determined by Kjeldahl's method using the 6.38 conversion factor.

\subsection{Surface hydrophobicity}

The surface hydrophobicity of WPI and WPC was determined using $1 \mathrm{~mL} 0.1 \%$ protein solution mixed with $1 \mathrm{~mL}$ of $4 \times 10^{-5} \mathrm{~mol} \cdot \mathrm{L}^{-1}$ 1-anilinonaphtalene-8-sulphonate (ANS) at ambient temperature [27]. The fluorescence intensity was recorded on a PerkinElmer LS 50 spectrofluorimeter (excitation at $365 \mathrm{~nm}$, emission at $470 \mathrm{~nm}$ ).

\subsection{Foaming properties}

For foaming properties evaluation, $10 \%$ $(\mathrm{w} / \mathrm{w})$ protein dispersions were whipped at room temperature with a mixer (MSM5220, Bosch, Germany) equipped with a wire whip beater at maximum speed settings (12 $000 \mathrm{rpm})$ for $15 \mathrm{~min}$. Whipping was interrupted every $5 \mathrm{~min}$ to determine foam expansion. Foam expansion was determined by level-filling a $100-\mathrm{mL}$ plastic weighing boat with foam and weighing to $\pm 0.01 \mathrm{~g}$. Afterwards, foam expansion was computed using the following expression:

Foam expansion $(\%)=$

Unwhipped dispersion wt $(\mathrm{g})-$ Foam wt $(\mathrm{g})$ Unwhipped dispersion wt(g)

$$
\times 100 .
$$

After the foam expansion was determined, the foam was returned to the bowl and whipping was resumed for an additional 5 -min period. Foam stability was determined by transferring $100 \mathrm{~mL}$ of maximum expansion foam into a filter funnel. A small plug of glass wool was placed in the top of the funnel stem to retain the foam but allow drainage of the liquid. The time required for the first drop of liquid to drain from the funnel was determined as an index of foam stability. The time for drainage of all of the foam was determined and expressed as maximum foam stability [38].

\subsection{Emulsifying properties}

The emulsion stability index (ESI) and emulsifying activity index (EAI) for the protein- stabilised emulsions were determined by the turbidimetric technique [6]. For evaluation of emulsifying properties, emulsions were prepared by mixing protein dispersions $\left(30 \mathrm{~g} \cdot \mathrm{kg}^{-1}\right)$ and $10 \mathrm{~mL}$ of sunflower oil in a ratio $1: 2$, for $90 \mathrm{~s}$ in a blender (Philips, Hamburg, Germany, model HR 
2304). In the final emulsion, oil quantity was $0.67 \mathrm{~L} \cdot \mathrm{L}^{-1}$ and protein quantity was $0.15 \mathrm{~g} \cdot \mathrm{L}^{-1}$, respectively. The range of oil droplet sizes of control emulsions was established under $200 \times$ magnification using a light microscope (Universal TransmittedLight Microscope: model Axioskop; Carl Zeiss MicroImaging, GmbH, Jena, Germany).

One millilitre of freshly prepared emulsions was pipetted out and serially diluted with $99 \mathrm{~mL}$ of distilled water (a hundredfold) followed by $1 \mathrm{~mL}$ of the diluted emulsion into $39 \mathrm{~mL}$ (forty-fold) of $1 \mathrm{~g} \cdot \mathrm{kg}^{-1}$ SDS (to avoid flocculation), resulting in a fourthousand-fold total dilution. Absorbance of the final dispersions was measured at $500 \mathrm{~nm}$ (Helios- $\beta$ Spectrophotometer, Pye Unicam Ltd, Cambridge, UK) and the turbidity was calculated using the following formula:

$$
T=\frac{2.303 \times A}{l}
$$

where $T$ is turbidity, $A$ is absorbance at $500 \mathrm{~nm}$ and $l$ is the path length of the cuvette $(\mathrm{m})$. Emulsions were placed under refrigeration at $4{ }^{\circ} \mathrm{C}$ and were gently redispersed for analysis after $24 \mathrm{~h}$. The ESI and EAI were determined as follows:

$\operatorname{ESI}(\mathrm{h})=\left(A_{0} / \Delta A\right) \times t$; where $A_{0}$ is the absorbance of the diluted emulsion immediately after formation, $\Delta A$ is the change in absorbance between 0 and $24 \mathrm{~h}\left(\mathrm{~A}_{0}-\mathrm{A}_{24}\right)$ and $t$ is the time interval, $24 \mathrm{~h}$ in this case.

$$
\operatorname{EAI}\left(\mathrm{m}^{2} \cdot \mathrm{g}^{-1}\right)=\frac{2 \times T \times \text { dilution factor }}{C \times \Phi} ;
$$

where $C$ is the weight of protein per unit volume of protein aqueous phase before emulsion formation, $\Phi$ is the oil volume fraction of the emulsion ( 0.67 in this case) and the dilution factor was 4000 .

\subsection{Statistical analysis}

The whole study was repeated and each value represents the mean of four measurements from two independent high-pressure treatments. The effect of high-pressure treatment on the investigated functional properties was determined by two-way analysis of variance, using SPSS 10.0 for
Table I. Solubility (mean \pm standard deviation of four measurements) of control and highpressure-treated WPC determined at $\mathrm{pH} 4.6$ and at $\mathrm{pH}$ 7.0.

\begin{tabular}{lcc}
\hline \multirow{2}{*}{$\begin{array}{l}\text { Processing } \\
\text { conditions }\end{array}$} & \multicolumn{2}{c}{ Solubility $\left(\mathrm{g} \cdot 100 \mathrm{~g}^{-1}\right)$} \\
\cline { 2 - 3 } & $\mathrm{pH} 4.6$ & $\mathrm{pH} 7.0$ \\
\hline Control & $89.9 \pm 1.2^{\mathrm{a}}$ & $91.1 \pm 1.4^{\mathrm{a}}$ \\
$300 \mathrm{MPa} / 5 \mathrm{~min}$ & $76.2 \pm 2.1^{\mathrm{b}}$ & $86.3 \pm 1.1^{\mathrm{b}}$ \\
$300 \mathrm{MPa} / 10 \mathrm{~min}$ & $72.6 \pm 1.1^{\mathrm{c}}$ & $84.7 \pm 1.7^{\mathrm{b}}$ \\
$600 \mathrm{MPa} / 5 \mathrm{~min}$ & $65.1 \pm 2.2^{\mathrm{d}}$ & $81.4 \pm 1.2^{\mathrm{c}}$ \\
$600 \mathrm{MPa} / 10 \mathrm{~min}$ & $65.0 \pm 2.4^{\mathrm{d}}$ & $78.9 \pm 1.8^{\mathrm{c}}$ \\
\hline
\end{tabular}

Different letters in the same column indicate significant differences $(P<0.05)$ according to Duncan's multiple range test.

Windows software (Statistical Package for the Social Sciences, version 10.0). To test significant differences between the means Duncan's multiple range test was used. The significance level used was $5 \%(\alpha=0.05)$.

\section{RESULTS AND DISCUSSION}

\subsection{Effect of high pressure on the solubility and surface hydropho- bicity of WPC and WPI}

The solubility at $\mathrm{pH} 7.0$ or at $\mathrm{pH} 4.6$ of control and samples pressurised for 5 or 10 min was determined by measuring the protein concentration in the supernatant after centrifugation, and it should be considered a reliable predictor of functionality. The value for solubility of non-pressurised samples measured at $\mathrm{pH} 7.0$ was high, and it varied from $91.1 \pm 1.4 \mathrm{~g} \cdot 100 \mathrm{~g}^{-1}$ for WPC (Tab. I) to $96.6 \pm 1.5 \mathrm{~g} \cdot 100 \mathrm{~g}^{-1}$ for WPI (Tab. II). These high values reflect the high proportion of native whey proteins present in industrial products. The solubility of both control samples remained relatively high (in a range of $89.9 \pm 1.2 \mathrm{~g} \cdot 100 \mathrm{~g}^{-1}$ to $95.8 \pm 1.5 \mathrm{~g} \cdot 100 \mathrm{~g}^{-1}$ ), also measured at $\mathrm{pH}$ 4.6, which is close to the isolectric point of whey proteins. Solubility of WPC and WPI at $\mathrm{pH} 4.6$ is a useful tool for estimating the degree of protein denaturation [38]. When protein solubility is measured near the 
Table II. Solubility (mean \pm standard deviation of four measurements) of control and highpressure-treated WPI determined at $\mathrm{pH} 4.6$ and at $\mathrm{pH}$ 7.0.

\begin{tabular}{lcc}
\hline $\begin{array}{l}\text { Processing } \\
\text { conditions }\end{array}$ & \multicolumn{2}{c}{ Solubility $\left(\mathrm{g} \cdot 100 \mathrm{~g}^{-1}\right)$} \\
\cline { 2 - 3 } & $\mathrm{pH} 4.6$ & $\mathrm{pH} 7.0$ \\
\hline Control & $95.8 \pm 1.5^{\mathrm{a}}$ & $96.6 \pm 1.5^{\mathrm{a}}$ \\
$300 \mathrm{MPa} / 5 \mathrm{~min}$ & $68.2 \pm 1.8^{\mathrm{b}}$ & $88.4 \pm 2.1^{\mathrm{b}}$ \\
$300 \mathrm{MPa} / 10 \mathrm{~min}$ & $64.3 \pm 2.1^{\mathrm{c}}$ & $85.1 \pm 2.4^{\mathrm{b}}$ \\
$600 \mathrm{MPa} / 5 \mathrm{~min}$ & $61.1 \pm 0.9^{\mathrm{d}}$ & $81.7 \pm 0.9^{\mathrm{c}}$ \\
$600 \mathrm{MPa} / 10 \mathrm{~min}$ & $58.1 \pm 2.2^{\mathrm{d}}$ & $76.2 \pm 1.2^{\mathrm{d}}$ \\
\hline
\end{tabular}

Different letters in the same column indicate significant differences $(P<0.05)$ according to Duncan's multiple range test.

isoelectric point of proteins, isoelectric precipitation is stimulated, leading to the removal of highly aggregated proteins.

After pressurisation, a significant reduction in protein solubility $(P<0.05)$, measured at $\mathrm{pH} 7.0$ and $\mathrm{pH} 4.6$, was found for all protein dispersions which were tested. The decrease was dependent on the intensity of applied pressure and the duration of pressure treatment, and consequently, for both samples, was the most pronounced when pressurisation was performed at $600 \mathrm{MPa}$ for $10 \mathrm{~min}$. Protein solubility of WPI, measured at $\mathrm{pH} 4.6$ after processing at $600 \mathrm{MPa}$ for $5 \mathrm{~min}$ decreased to $61.1 \pm 0.9 \mathrm{~g} \cdot 100 \mathrm{~g}^{-1}$ and to $58.1 \pm 2.2 \mathrm{~g} \cdot 100 \mathrm{~g}^{-1}$ after $10 \mathrm{~min}$ at the same pressure, respectively (Tab. II). Under the same treatment conditions, WPC samples showed solubility close to $65 \mathrm{~g} \cdot 100 \mathrm{~g}^{-1} \quad$ (Tab. I). The diminished effect of high pressure on whey protein concentrate in comparison with the whey protein isolate could be explained by the smaller amount of proteins $(6.13 \%(\mathrm{w} / \mathrm{w})$ in WPC compared with $9.78 \%(\mathrm{w} / \mathrm{w})$ in WPI counted on $10 \%(\mathrm{w} / \mathrm{w})$ powder) and the presence of a significant amount of lactose. The baroprotective effects of disaccharides during pressurisation were previously reported, in similar, but not the same systems [10].

The lowest solubility values in all investigated samples may be attributed to the increased aggregation after pressure release. Since protein solubility at $\mathrm{pH} 7.0$ signifi-
Table III. Influence of high-pressure treatments on surface hydrophobicity of WPC and WPI in aqueous solution $\left(0.1 \% \mathrm{w} / \mathrm{w}\right.$ protein, $4 \times 10^{-5}$ moldm ${ }^{-3}$ ANS).

\begin{tabular}{lcc}
\hline $\begin{array}{l}\text { Processing } \\
\text { conditions }\end{array}$ & \multicolumn{2}{c}{ Fluorescence intensity (I)* } \\
\cline { 2 - 3 } & WPC & WPI \\
\hline Control & $8.1 \pm 0.2^{\mathrm{c}}$ & $12.4 \pm 0.1^{\mathrm{c}}$ \\
$300 \mathrm{MPa} / 5 \mathrm{~min}$ & $8.3 \pm 0.1^{\mathrm{c}}$ & $13.0 \pm 0.2^{\mathrm{b}}$ \\
$300 \mathrm{MPa} / 10 \mathrm{~min}$ & $8.6 \pm 0.1^{\mathrm{b}}$ & $13.3 \pm 0.2^{\mathrm{b}}$ \\
$600 \mathrm{MPa} / 5 \mathrm{~min}$ & $10.0 \pm 0.3^{\mathrm{a}}$ & $15.7 \pm 0.4^{\mathrm{a}}$ \\
$600 \mathrm{MPa} / 10 \mathrm{~min}$ & $10.3 \pm 0.3^{\mathrm{a}}$ & $16.1 \pm 0.4^{\mathrm{a}}$ \\
\hline
\end{tabular}

* Quoted values are the averages of four measurements. Different letters in the same column indicate significant differences $(P<0.05)$ according to Duncan's multiple range test.

cantly decreased $(P<0.05)$ after pressurisation, it indicates that the net charge or the surface hydrophobicity was modified by pressure processing. It seems possible that protein aggregation after pressure release, confirmed with decreased solubility measured at $\mathrm{pH} 4.6$, is related to an increase in the globular protein surface hydrophobicity which resulted in the unmasking of previously hidden hydrophobic groups, as shown in Table III.

The data presented in this paper suggest that the formation of hydrophobic interactions, which are necessary for aggregate formation upon pressure release, may be extensive in the systems under investigation. Since it was revealed that the major protein component can primarily determine the functional behaviour of whey protein isolate or whey protein concentrate under the influence of high pressure [5], and taking into account that the amount of $\beta$-lactoglobulin in BiPRO is $73 \%(w / w)$ [36], we conducted a preliminary experiment on this project, with the aim of examining the susceptibility of pure $\beta$-lactoglobulin to aggregation under the same conditions of highpressure treatment. The obtained optical density data showed strong aggregation of $\beta$-lactoglobulin even at $300 \mathrm{MPa}$ [32]. According to these results we also expected an aggregation phenomenon in WPC and WPI dispersions after pressurisation at $300 \mathrm{MPa}$, which was confirmed in this work. 


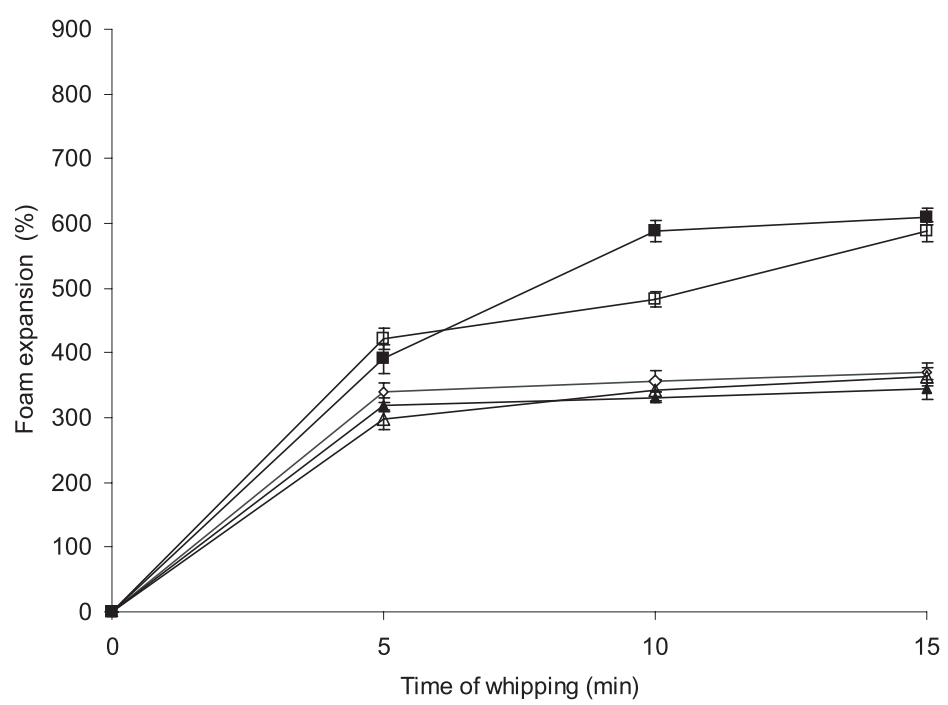

Figure 1. Foam expansion of the control WPC dispersion $(10 \% \mathrm{w} / \mathrm{w})(\diamond)$ and WPC dispersions $(10 \% \mathrm{w} / \mathrm{w})$ treated with high pressure under the following conditions: $300 \mathrm{MPa} / 5 \mathrm{~min}(\mathbf{\square})$; $300 \mathrm{MPa} / 10 \mathrm{~min}(\square) ; 600 \mathrm{MPa} / 5 \min (\Delta) ; 600 \mathrm{MPa} / 10 \min (\triangle)$. Bars indicate the standard deviation of four measurements.

\subsection{Effect of high-pressure treatment of WPC and WPI on their foaming ability and foaming stability}

Foaming properties of WPC and WPI are commonly determined as maximum foam expansion, and foam stability. Under the same whipping conditions, control WPC (Fig. 1) exhibited reduced foam ability (foam expansion of $369 \%$ ) compared with WPI $(484 \%)$ due to their different composition (Fig. 2). The residual fat content in WPC has been considered as detrimental to foam formation and may even cause the foam lamella to break [29]. During whipping of all dispersions under investigation, foam volume increased with prolonged whipping time, as summarised in Figures 1 and 2. The most pronounced increase in the percentage of foam volume expansion was after the first 5 min of whipping and it slowed down during prolonged whipping. After the incorporation of a large quantity of air (40-60\% volume), big bubbles occur in the first stage. Subsequently, the bubble size gets smaller and a narrower bubble size distribution is reached, while proteins form a cohesive intramolecular densely-packed film [40]. Control WPI (Tab. V) formed more stable foam, with a value for the maximum foam stability index of $290 \pm 3.33 \mathrm{~min}$, in comparison with the value for control WPC $(210 \pm 2.32 \mathrm{~min})$ (Tab. IV). This is attributed to the previously discussed significant amount of $\beta$-lactoglobulin, which is capable of forming a thicker and more viscous film, thus improving foam stability [49].

After high-pressure processing of WPC, progressive loss of foaming ability was observed with the extension of treatment time. Pressure processing at $600 \mathrm{MPa}$ caused a reduction in the foam volume of up to $363 \%$ due to formation of aggregates, which occurred after pressure release (Fig. 1). The role of proteins in foam film formation is in lowering interfacial tension. They concentrate at the cell interface, where they undergo partial unfolding and subsequent interaction via intermolecular bonding, which results in a cohesive film and stabilises the foam cells [1]. Aggregation 


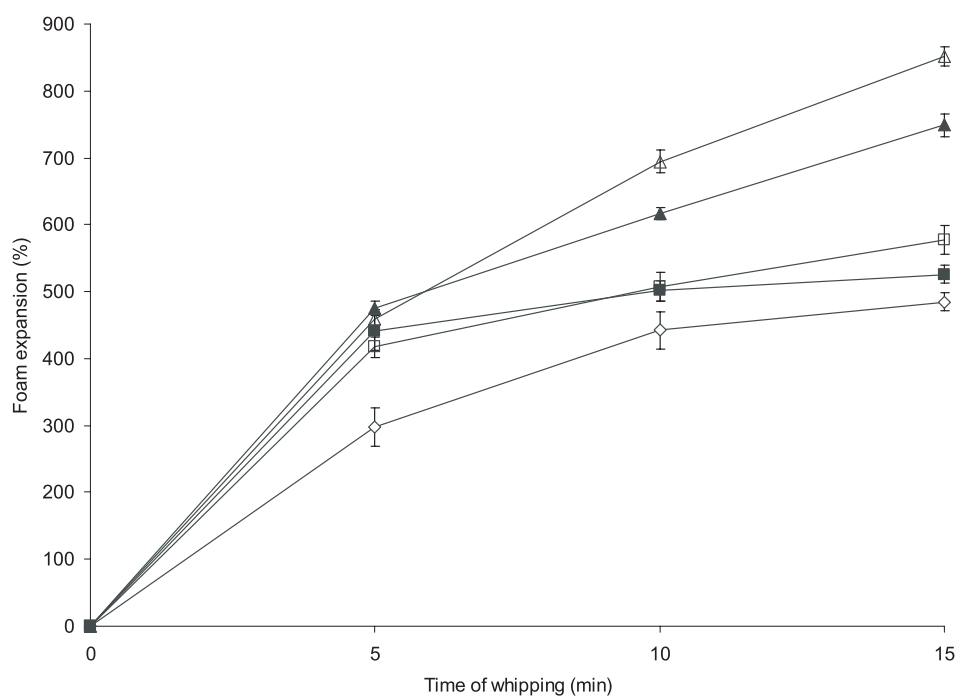

Figure 2. Foam expansion of the control WPI dispersion $(10 \% \mathrm{w} / \mathrm{w})(\diamond)$ and WPI dispersions $(10 \% \mathrm{w} / \mathrm{w})$ treated with high pressure under the following conditions: $300 \mathrm{MPa} / 5 \mathrm{~min}(\mathbf{\square})$; $300 \mathrm{MPa} / 10 \mathrm{~min}(\square) ; 600 \mathrm{MPa} / 5 \min (\Delta) ; 600 \mathrm{MPa} / 10 \min (\triangle)$. Bars indicate the standard deviation of four measurements.

reduces the amount of protein available for film formation, but the films that are formed are considered to be thicker and more stable, facilitating the formation of a network structure in the protein film that results in improved rheological properties of the film, thereby increasing foam stability. It is suggested that cross-linking through S-S bridges gives good viscoelastic film formation [33]. This phenomenon was supported by the significantly increased value $(P<0.05)$ for foam stability and maximum foam stability indexes after high-pressure processing, as summarised in Table IV. High-pressure processing caused the foam stability index to increase from $1.10 \pm 0.36 \mathrm{~min}$ (after treatment at $300 \mathrm{MPa} / 5 \mathrm{~min}$ ) to $6.54 \pm 1.32 \mathrm{~min}$ (after $10 \mathrm{~min}$ at $600 \mathrm{MPa}$ ). Additionally, the maximum foam stability increased almost four-fold.

On the contrary, it was observed that increase in both hydrostatic pressure and treatment time significantly improved the foaming ability of WPI. The maximum value for foam expansion $(851 \%)$ was
Table IV. Foam stability indicators (mean \pm standard deviation of four measurements) for $10 \%(\mathrm{w} / \mathrm{w})$ model dispersions prepared with control and pressure-treated WPC.

\begin{tabular}{lcc}
\hline $\begin{array}{l}\text { Processing } \\
\text { conditions }\end{array}$ & $\begin{array}{c}\text { Foam stability } \\
\text { index (min) }\end{array}$ & $\begin{array}{c}\text { Maximum foam } \\
\text { stability (min) }\end{array}$ \\
\hline Control & $0.50 \pm 0.02^{\mathrm{d}}$ & $210 \pm 2.32^{\mathrm{e}}$ \\
$300 \mathrm{MPa} / 5 \mathrm{~min}$ & $1.10 \pm 0.36^{\mathrm{c}}$ & $325 \pm 8.75^{\mathrm{d}}$ \\
$300 \mathrm{MPa} / 10 \mathrm{~min}$ & $2.10 \pm 0.50^{\mathrm{b}}$ & $475 \pm 6.22^{\mathrm{c}}$ \\
$600 \mathrm{MPa} / 5 \mathrm{~min}$ & $5.38 \pm 1.12^{\mathrm{a}}$ & $728 \pm 7.55^{\mathrm{b}}$ \\
$600 \mathrm{MPa} / 10 \mathrm{~min}$ & $6.54 \pm 1.32^{\mathrm{a}}$ & $915 \pm 9.77^{\mathrm{a}}$ \\
\hline
\end{tabular}

Different letters in the same column indicate significant differences $(P<0.05)$ according to Duncan's multiple range test.

reached in samples processed at $600 \mathrm{MPa}$ for $10 \mathrm{~min}$ (Fig. 2). The intensity and the duration of high-pressure treatment are the most important parameters affecting the foaming behaviour of WPI. Whipping of $10 \%(\mathrm{w} / \mathrm{w})$ protein dispersion ensures the 
Table V. Foam stability indicators (mean \pm standard deviation of four measurements) for $10 \%(\mathrm{w} / \mathrm{w})$ model dispersions prepared with control and pressure-treated WPI.

\begin{tabular}{lcc}
\hline $\begin{array}{l}\text { Processing } \\
\text { conditions }\end{array}$ & $\begin{array}{c}\text { Foam stability } \\
\text { index (min) }\end{array}$ & $\begin{array}{c}\text { Maximum foam } \\
\text { stability (min) }\end{array}$ \\
\hline Control & $2.24 \pm 0.77^{\mathrm{c}}$ & $290 \pm 3.33^{\mathrm{e}}$ \\
$300 \mathrm{MPa} / 5 \mathrm{~min}$ & $3.50 \pm 1.33^{\mathrm{b}}$ & $420 \pm 7.32^{\mathrm{d}}$ \\
$300 \mathrm{MPa} / 10 \mathrm{~min}$ & $4.16 \pm 1.22^{\mathrm{c}}$ & $789 \pm 7.10^{\mathrm{c}}$ \\
$600 \mathrm{MPa} / 5 \mathrm{~min}$ & $10.25 \pm 2.20^{\mathrm{a}}$ & $701 \pm 8.45^{\mathrm{b}}$ \\
$600 \mathrm{MPa} / 10 \mathrm{~min}$ & $11.35 \pm 2.12^{\mathrm{a}}$ & $1032 \pm 9.75^{\mathrm{a}}$ \\
\hline
\end{tabular}

Different letters in the same column indicate significant differences $(P<0.05)$ according to Duncan's multiple range test.

concentration of surface-active proteins available for the initial bubble formation. On the other hand, since previously hidden hydrophobic groups in the partially unfolded protein became exposed following pressure treatments (Tab. III) and proteins became more flexible to adsorb at a faster rate, they, in combination with an amount of surfaceactive proteins, are capable of counteracting the negative effects of aggregation and thus affect the foaming properties of WPI in a favourable manner. The foaming properties strongly correlate with the surface hydrophobicity [42]. Following an initial rapid drainage, macroscopic foams formed from dispersions of high-pressure-treated WPI were shown to persist over long periods of time with significant influence $(P<0.05)$ on pressure intensity and treatment duration (Tab. V). Protein aggregation imparts thickness to the film and retards the drainage of lamella liquid.

\subsection{Influence of high pressure on emulsifying properties of WPC and WPI}

The indices for emulsifying properties (ESI and EAI) of the emulsions produced using the control and high-pressure-treated whey protein concentrate and isolate are summarised in Tables VI and VII. There is a significant difference $(P<0.05)$ between the EAI values for WPC and WPI. The control WPI is characterised by the possibility
Table VI. Emulsifying activity index (EAI) and emulsion stability index (ESI) of emulsions prepared with control and pressuretreated WPC.

\begin{tabular}{lcc}
\hline $\begin{array}{l}\text { Processing } \\
\text { conditions }\end{array}$ & EAI $\left(\mathrm{m}^{2} \cdot \mathrm{g}^{-1}\right)^{*}$ & ESI $(\mathrm{h})^{*}$ \\
\hline Control & $117.81 \pm 3.21^{\mathrm{a}}$ & $70.54 \pm 1.11^{\mathrm{a}}$ \\
$300 \mathrm{MPa} / 5 \mathrm{~min}$ & $113.45 \pm 2.11^{\mathrm{b}}$ & $68.72 \pm 0.39^{\mathrm{b}}$ \\
$300 \mathrm{MPa} / 10 \mathrm{~min}$ & $112.45 \pm 1.97^{\mathrm{b}}$ & $67.86 \pm 0.62^{\mathrm{b}}$ \\
$600 \mathrm{MPa} / 5 \min$ & $109.07 \pm 1.35^{\mathrm{c}}$ & $64.55 \pm 2.14^{\mathrm{c}}$ \\
$600 \mathrm{MPa} / 10 \mathrm{~min}$ & $106.42 \pm 1.52^{\mathrm{c}}$ & $62.25 \pm 2.47^{\mathrm{c}}$ \\
\hline
\end{tabular}

* Quoted values are the averages of four measurements.

Different letters in the same column indicate significant differences $(P<0.05)$ according to Duncan's multiple range test.

Table VII. Emulsifying activity index (EAI) and emulsion stability index (ESI) of emulsions prepared with control and pressuretreated WPI .

\begin{tabular}{lcc}
\hline $\begin{array}{l}\text { Processing } \\
\text { conditions }\end{array}$ & EAI $\left(\mathrm{m}^{2} \cdot \mathrm{g}^{-1}\right)^{*}$ & ESI $(\mathrm{h})^{*}$ \\
\hline Control & $148.21 \pm 1.56^{\mathrm{a}}$ & $72.18 \pm 1.89^{\mathrm{a}}$ \\
$300 \mathrm{MPa} / 5 \mathrm{~min}$ & $147.88 \pm 1.71^{\mathrm{a}}$ & $68.14 \pm 2.03^{\mathrm{b}}$ \\
$300 \mathrm{MPa} / 10 \min$ & $147.16 \pm 1.65^{\mathrm{a}}$ & $67.88 \pm 1.78^{\mathrm{b}}$ \\
$600 \mathrm{MPa} / 5 \mathrm{~min}$ & $144.01 \pm 1.34^{\mathrm{b}}$ & $65.11 \pm 0.85^{\mathrm{c}}$ \\
$600 \mathrm{MPa} / 10 \min$ & $143.66 \pm 1.18^{\mathrm{b}}$ & $64.34 \pm 1.82^{\mathrm{c}}$ \\
\hline
\end{tabular}

* Quoted values are the averages of four measurements.

Different letters in the same column indicate significant differences $(P<0.05)$ according to Duncan's multiple range test.

of stabilising a greater interface area per unit weight of protein compared with WPC, which can be quantified with a higher value of EAI $\left(148.21 \pm 1.56 \mathrm{~m}^{2} \cdot \mathrm{g}^{-1}\right.$ vs. $\left.117.81 \pm 3.21 \mathrm{~m}^{2} \cdot \mathrm{g}^{-1}\right)$. The presence of lactose and lipids in WPC prevent protein propagation at the interface surface, resulting in decreased values of the emulsion activity index [50]. The higher value for EAI of WPI is also related to its protein composition. WPI contains a significant amount of $\beta$-lactoglobulin (73\%), which is known to be the major functional protein 
and whose molecular flexibility and conformation changes at the water-oil interface enable it to act like an emulsifier [9]. Additionally, according to manufacturers, because of the ion-exchange method used in manufacturing processes, significant amounts of $\alpha$-lactalbumin, BSA, immunoglobulins and lactoferrin are maintained in selected WPI. It contains less than 5\% non-protein nitrogen (NPN).

In food emulsions, proteins play two major roles: on the one hand, they lower surface tension between the interfaces that are formed during the emulsification process, and on the other hand, they form a macromolecular layer surrounding the dispersed particles which structurally stabilises the emulsions by reducing the rate of coalescence, flocculation and oiling off $[4,8,20]$.

The interfacial area which could be stabilised with one gram of WPI did not change significantly $(P>0.05)$ after pressurisation at $300 \mathrm{MPa}$. Hence, a significant decrease $(P<0.05)$ occurred after pressure treatment at $600 \mathrm{MPa}$ for 5 and $10 \mathrm{~min}$, respectively (Tab. VII.). On the contrary, a greater loss $(P<0.05)$ of the overall emulsifying efficiency of WPC was evident after pressurising even at $300 \mathrm{MPa}$ (Tab. VI). It was expected that partial denaturation of proteins, with the resultant unfolding accompanied by increased surface hydrophobicity, should improve emulsifying efficiency. However, it could be seen that the proportion of proteins which could be adsorbed at the oil-water interface was insufficient to overcome the amounts of aggregated proteins that had destabilised emulsion. The complicated effects of pressure on emulsifying properties additionally could be explained by a change in conformation of the whey proteins during the emulsification process. Only a small part of the whey protein is likely to be absorbed at the water/oil interface in the coarse emulsion, because the kinetics of absorption requires a much longer time than that for emulsification.

Emulsions prepared with control WPI exhibited slightly prolonged stability in comparison with WPC $(72.18 \pm 1.89 \mathrm{~h}$ vs. $70.54 \pm 1.11 \mathrm{~h}$ ), as summarised in Tables VI and VII. This general observation is quite consistent with the measured oil droplet range (for emulsions prepared with control WPC oil droplet diameter was in the range of $0.38-0.56 \mu \mathrm{m}$, while for emulsions stabilised with control WPI oil droplet diameter was in the range of $0.25-0.35 \mu \mathrm{m})$, since emulsions with smaller oil droplet size should be more stable than those with larger droplets. Generally speaking, emulsions that are stabilised solely by protein are very stable to coalescence, provided sufficient protein is available to fully cover the droplet surface [46]. The most important single property of a protein-stabilised emulsion is the maintenance of emulsion throughout the storage period of the product. In stable emulsions the interfacial area does not change with time. However, if it occurs, coalescence causes an irreversible reduction in interfacial area, and the rates of these processes can be monitored using turbidimetry. In this experiment, the effect of high pressure on emulsifying properties of WPC and WPI was shown in terms of increased values of turbidity (during a storage period of one day) which is obvious in calculated values for emulsifying indices. According to these results (Tabs. VI and VII), it could be assumed that there was a trend toward larger droplet size with increasing pressure and treatment time. There are a number of possible reasons to account for the increase in mean droplet size: (i) the total droplet surface area that could be stabilised by the protein decreased; (ii) the rate at which the droplet surfaces were covered with protein decreased; and (iii) the frequency of droplet collisions increased due to the decrease in aqueous phase viscosity. All of these factors facilitate droplet disruption and lead to droplet coalescence, thereby leading to the formation of larger droplet sizes [34]. According to other researchers, in emulsions prepared with pressure-treated $\beta$-lactoglobulin as the emulsifier it was shown that substantially larger droplets occurred compared with those made with the native protein [13]. Consequently, in our experiment, a significant decrease $(P<0.05)$ in emulsion stability occurred in all samples after pressure treatment. The detrimental effect of high pressure was more evident in WPI (Tab. VII) due to the previously 
discussed greater solubility loss accompanied by aggregation after pressurisation. Solubility, together with surface hydrophobicity, are also known as important properties for maintaining a stable emulsion [13].

It must be concluded that the positive effect of an increased surface hydrophobicity on emulsifying capacity is outweighed by the negative effect of protein aggregation, which makes less protein available for saturating the freshly formed interface with a monolayer of sterically stabilising globular protein molecules.

\section{CONCLUSION}

This study is part of a larger assessment of the effect of high pressure on model systems prepared with whey proteins in view of the application of high-pressure processing to the modification of functional properties of protein-rich foods.

The results presented in this paper demonstrate that pressure-induced changes in WPC and WPI greatly influence their solubility and surface hydrophobicity. Solubility decrease in combination with protein aggregation was related to the intensity of applied pressure and treatment time. These effects were much more evident in WPI model systems.

Pressurised WPI had significantly higher foam expansion, foam volume stability and foam liquid stability than the control samples due to the amount of available surfaceactive proteins which could ensure superior functional properties. High-pressure treatment at $600 \mathrm{MPa}$ enhanced the foam formation properties of WPC, which was followed by improved foam stability due to retaining the drainage of lamella liquid. The detrimental effect of high-pressure processing on the emulsifying activity of WPI was noted after pressurisation at $600 \mathrm{MPa}$, whereas for WPC it was observed after pressurisation as low as $300 \mathrm{MPa}$. Rapid creaming, together with the loss of emulsifying stability, occurred in all emulsions prepared with high-pressure-treated whey proteins.

It should be mentioned that the phenomena taking place in the present model system do not necessarily predict the behaviour of whey proteins in commercial dairy foods, since the presence of other components (sugars, fats, other proteins, etc.) could modify the observed behaviour. Further research is underway to optimise the conditions of high-pressure treatment, in order to obtain enhanced functional properties related to protein-water interactions.

Acknowledgements: This study was funded by the Croatian Ministry of Science and Technology (Project No. 0058021). We thank Prof. Dietrich Knorr at the Berlin University of Technology, Department of Food Biotechnology and Food Process Engineering for providing access to high-pressure equipment and for fruitful advices.

\section{REFERENCES}

[1] Adebowale K.O., Lawal O.S., Foaming, gelation and electrophoretic characteristics of mucuna bean proteins concentrates, Food Chem. 83 (2003) 237-246.

[2] Arias M., Lopez-Fandino R., Olano A., Influence of $\mathrm{pH}$ on the effects of high pressure on milk proteins, Milchwissenschaft 55 (2000) 191-194.

[3] Boye J.I., Alli I., Ramaswamy H., Reghvan V.G.S., Interactive effects of factor affecting gelation of whey proteins, J. Food Sci. 62 (1997) 57-65

[4] Challis R.E., Povey M.J.W., Mather M.L., Holmes A.K., Ultrasound techniques for characterizing colloidal dispersions, Rep. Prog. Phys. 68 (2005) 1541-1637.

[5] Cheftel J.C., Effects of high hydrostatic pressure on food constituents: an overview, in: Balny C., Hayashi R., Heremans K., Masson P. (Eds.), High Pressure and Biotechnology, John Libbey Eurotext, Montrouge, France, 1992, pp. 195-208.

[6] Chove B.E., Grandison A.S., Lewis M.J., Emulsifying properties of soy protein isolates obtained by microfiltration, J. Sci. Food Agr. 82 (2002) 267-272.

[7] Corradini C., Functional properties of whey proteins in foods, Sci. Tecn. Latt.-Cas. 49 (1998) 204-213.

[8] Dalgleish D.G., Food Emulsions, in: Sjöblom J. (Ed.), Emulsions and Emulsion Stability, Marcel Dekker, New York, USA, 1996, pp. 287-325. 
[9] Dickinson E., Galazka V.B., Emulsion stabilization by ionic and covalent complexes of $\beta$-lactoglobulin with polysaccharides, Food Hydrocoll. 5 (1991) 281-296.

[10] Dumay E.M., Kalichevsky M.T., Cheftel J.C., High pressure unfolding and aggregation of $\beta$-lactoglobulin and the baroprotective effects of sucrose, J. Agric. Food Chem. 42 (1994) 1861-1868.

[11] Faergemand M., Otte J., Qvist K.B., Crosslinking of whey proteins by enzymic oxidation, J. Agric. Food Chem. 46 (1998) 1326-1333.

[12] Funtenberger S., Dumay E., Cheftel J.C., Pressure induced aggregation of $\beta$-lactoglobulin in $\mathrm{pH} 7.0$ buffers, Lebensm.Wiss. Technol. 28 (1995) 410-418.

[13] Galazka V.B., Dickinson E., Ledward D.A., Effect of high-pressure on the emulsifying behaviour of $\beta$-lactoglobulin, Food Hydrocoll. 10 (1996) 213-219.

[14] Harper W.J., Biological Properties of Whey Components: A Review, American Dairy Product Institute, Chicago IL, 2000, pp. 1-67.

[15] Herceg Z., Lelas V., Brčnić M., Tripalo B., Ježek D., Fine milling and micronization of organic and inorganic materials under dynamic conditions, Powder Technol. 139 (2004) 111-117.

[16] Herceg Z., Lelas V., Krešić G., Influence of tribomechanical micronization on the physical and functional properties of whey proteins, Int. J. Dairy Technol. 58 (2005) 225-232.

[17] Hinrichs J., Rademacher B., Kinetics of combined thermal and pressure-induced whey protein denaturation in bovine skim milk, Int. Dairy J. 14 (2004) 315-323.

[18] Hudson H.M., Daubert C.R., Foegeding E.A., Rheological and physical properties of derivatized whey protein isolate powders, J. Agric. Food Chem. 48 (2000) 3112-3119.

[19] Huffman L.M., Processing whey protein for use as a food ingredient, Food Technol. 50 (1996) 49-52.

[20] Hunt J.A., Dalgleish D.G., Adsorption behaviour of whey protein isolate and caseinate in soya oil-in-water emulsions, Food Hydrocoll. 8 (1994) 175-187.

[21] Huppertz T., Fox P.F., Kelly A.L., High pressure treatment of bovine milk: effects on casein micelles and whey proteins, J. Dairy Res. 71 (2004) 97-106.

[22] Huppertz T., Fox P.F., Kelly A.L., High pressure-induced denaturation of $\alpha$-lactalbu- min and $\beta$-lactoglobulin in bovine milk and whey: a possible mechanism, J. Dairy Res. 71 (2004) 489-495.

[23] Huppertz T., Fox P.F., de Kruif K.G., Kelly A.L., High pressure-induced changes in bovine milk proteins: A review, Biochim. Biophys. Acta 1764 (2006) 593-598.

[24] Ibanoğlu E., Karataş S., High pressure effect on foaming behaviour of whey protein isolate, J. Food Eng. 47 (2001) 31-36.

[25] Ikeuchi Y., Nakagawa K., Endo T., Suzuki A., Hayashi T., Ito T., Pressure induced denaturation of monomer $\beta$-Lactoglobulin is partially irreversible: comparison of monomer form (highly acidic $\mathrm{pH}$ ) with dimmer form, J. Agric. Food Chem. 49 (2001) 40524059 .

[26] Kanno C., Mu T.-H., Hagiwara T., Ametani M., Azuma N., Gel formation from industrial milk whey proteins under hydrostatic pressure: effect of hydrostatic pressure and protein concentration, J. Agric. Food Chem. 46 (1998) 417-424.

[27] Kato A., Nakai S., Hydrophobicity determined by a fluorescence probe method and its correlation with surface properties of proteins, Biochim. Biophys. Acta 624 (1980) $13-20$

[28] Kato A., Osako Y., Matsudomi N., Kobayashi $\mathrm{K}$., Changes in the emulsifying and foaming properties of proteins during heat denaturation, Agric. Biol. Chem. 47 (1994) 33-37.

[29] Kinsella J.E., Whitehead D.M., Proteins in whey: chemical, physical and functional properties, Adv. Food Nutr. Res. 33 (1989) 343-348.

[30] Knorr D., Advantages, possibilities and challenges of high pressure applications in food processing, in: Reid D.S. (Ed.), The Properties of Water in Foods. Blackie, New York, USA, 1998, pp. 419-437.

[31] Korhonen H., Technology options for new nutritional concepts, Int. J. Dairy Technol. 55 (2002) 79-88.

[32] Krešić G., Lelas V., Herceg Z., Possibility of nutritional enrichment of whipped dairy products with whey proteins treated with high pressure, Mljekarstvo 55 (2005) 83-99.

[33] Ledward D.A., Effect of pressure on protein structure, High Pressure Res. 19 (2000) 1-10.

[34] McClements D.J., Food Emulsions: Principles, Practices, and Techniques, CRC Press, Boca Raton, 2004.

[35] Messens W., Van Camp J., Huyghebaert A., The use of high pressure to modify the 
functionality of food proteins, Trends Food Sci. Technol. 8 (1997) 107-112.

[36] Michel M., Leser M.E., Syrbe A., Clerc M.F., Bauwens I., Bovetto L., van Schack M.L., Watzke H.J., Pressure effects on whey protein-pectin mixtures, Lebensm.-Wiss. Technol. 34 (2001) 41-52.

[37] Mleko S., Foegeding E.A., pH induced aggregation and weak gel formation of whey protein polymers, J. Food Sci. 65 (2000) 139-143.

[38] Morr C.V., Foegeding E.A., Composition and functionality of commercial whey and milk protein concentrates and isolates: a status report, Food Technol. 44 (1990) 100-112.

[39] Nakai S., Li-Chane E., Recent advances in structure and function of food proteins: QSAR approach, Crit. Rev. Food Sci. 33 (1993) 477-499.

[40] Noda M., Shiinoki Y., Microstructure and rheological behaviour of whipping cream, J. Texture Stud. 17 (1986) 189-204.

[41] Pittia P., Wilde P.J., Husband F.A., Clark D.C., Functional and structural properties of beta-lactoglobulin as affected by high pressure treatment, J. Food Sci. 61 (1996) 11231128.

[42] Pittia P., Wilde P.J., Clark D.C., The effects of high pressure treatment on functional properties of $\beta$-casein and $\beta$-lactoglobulin, in: Heremans K. (Ed.), High Pressure Research in the Bioscience and Biotechnol- ogy, Leuven University Press, Leuven, Belgium, 1997, pp. 355-358.

[43] Severin S., Xia W.S., Enzymatic hydrolysis of whey proteins by two different proteases and their effect on the functional properties of resulting protein hydrolysates, J. Food Biochem. 30 (2006) 77-97.

[44] Tewari G., Jayas D.S., Holley R.A., High pressure processing of foods: an overview, Sci. Aliment 19 (1999) 619-661.

[45] U.S. Dairy Export Council Product specifications, Arlington, VA, USA, 1999.

[46] Van Aken G.A., Zoet F.D., Coalescence in highly concentrated coarse emulsions, Langmuir 16 (2000) 7131-7138.

[47] Van Camp J., Huyghebaert A., A comparative rheological study of heat and pressure induced whey protein gels, Food Chem. 54 (1995) 357-364

[48] Velez-Ruiz J.F., Swanson B.G., BarbosaCanovas G.V., Flow and viscoelastic properties of concentrated milk treated by high hydrostatic pressure, Lebensm.-Wiss. Technol. 31 (1998) 182-195.

[49] Zayas J.F., Functionality of proteins in food, Springer-Verlag, Berlin, Germany, 1997.

[50] Zhu H., Damodaran S., Heat-induced conformational changes in whey protein isolate and its relation to foaming properties, J. Agric. Food Chem. 42 (1994) 846-855. 